\title{
Extensor digitorum tendon rupture after anterior ankle arthroscopy
}

\section{Ruptura tetive ekstenzora digitoruma nakon prednje artroskopije gležnja}

\author{
Antun Šumanovac ${ }^{1 *}$, Robert Selthofer ${ }^{1}$, Tomislav Kokić2 ${ }^{2}$, Robert Mujkićs
}

\begin{abstract}
Aim: The aim of this paper is to increase awareness of orthopaedic surgeons about an uncommon yet possible complication of ankle arthroscopy - iatrogenic extensor digitorum rupture. Ankle arthroscopy is becoming more widespread and according to the literature, the complication rate varies from $9 \%$ up to $17 \%$. Case report: We are presenting a case of 32-year old police officer who recreationally plays soccer. The patient presented with clear signs of anterior ankle impingement confirmed by X-ray and the MRI. During ankle arthroscopy massive tibial and talar bone spurs were found with significant synovial reaction, nearly 10 loose intraarticular bodies and syndesmotic ossification. The patient was placed in a walking boot and early postoperative recovery went as planned. Physical therapy started 14 days after the procedure. Five weeks after the surgery while dorsiflexing his fingers patient felt a "snap" over his ankle followed by swelling. He couldn't dorsiflex his fingers afterwards. MRI showed a rupture of the common extensor digitorum tendon. The patient was treated with open reconstruction of the tendon and lower leg immobilisation for 6 weeks followed by physical therapy and partial weight bearing. The patient made a full recovery. Conclusion: It is of the utmost importance to keep in mind that ankle arthroscopy alongside it's obvious benefits is not void of complications. latrogenic tendon lesion is always possible and should be suspected with any loss of movement in foot and ankle after the procedure. Urgent MRI and immediate reconstruction showed good results in our case.
\end{abstract}

Key words: ankle; arthroscopy; complication; extensor digitorum; rupture; tendon
Sažetak. Cilj: Cilj prikaza je podići svijest ortopeda o vrlo rijetkoj no mogućoj komplikaciji artroskopije gležnja - jatrogenoj rupturi tetive ekstenzor digitoruma. Artroskopija gležnja postaje sve raširenija i prema literaturi učestalost komplikacija varira od $9 \%$ do $17 \%$. Prikaz slučaja: Prikazujemo slučaj 32-godišnjeg policajca koji se rekreativno bavi nogometom. Pacijent se javio s izraženim simptomima prednjeg sraza gležnja koji su potvrđeni RTG-om i MR-om. Tijekom artroskopije pronašli smo masivne koštane izdanke tibije i talusa uz znatnu sinovijalnu reakciju, 10 slobodnih zglobnih tijela te osifikaciju sindesmoze. Poslijeoperativno je postavljena hodna ortoza te je poslijeoperacijski oporavak išao prema planu. Fizikalna terapija započeta je 14 dana od zahvata. Pet tjedana od zahvata, kada je pacijent učinio dorzifleksiju prstiju, osjetio je kako je „nešto puknulo” u gležnju te se pojavila oteklina. Više nije mogao učiniti dorzifleksiju prstiju. MR je pokazao puknuće zajedničke tetive ekstenzora digitoruma. Pacijent je podvrgnut sekundarnom zahvatu - otvorenoj rekonstrukciji tetive te potom potkoljeničnoj imobilizaciji tijekom 6 tjedana. Potom je uslijedila fizikalna terapija te postepeno povećanje oslonca na operiranu nogu. Pacijent se potpuno oporavio. Zaključak: Neizmjerno je važno imati na umu kako artroskopija gležnja, osim svojih očitih prednosti, ima i ozbiljne komplikacije. Jatrogeno puknuće tetiva uvijek je moguće te ga treba imati na umu kod bilo kakvog gubitka pokreta u gležnju i stopalu nakon zahvata. Hitni MR te rekonstruktivni zahvat u našem su slučaju pokazali izvrsne rezultate.

Ključne riječi: artroskopija; ekstenzor digitorum; gležanj; komplikacija; puknuće; tetiva

\author{
${ }^{1}$ Department of Anatomy and Neuroscience, \\ Faculty of Medicine, University of Osijek, \\ Osijek, Croatia \\ ${ }^{2}$ Faculty of Medicine, University of Osijek, \\ Osijek, Croatia \\ ${ }^{3}$ Department of Anatomy, Histology, \\ Embriology, Pathological Anatomy and \\ Pathological Histology, Faculty of Dental \\ Medicine and Health, University of Osijek, \\ Osijek, Croatia
}

\author{
*Corresponding author: \\ Antun Šumanovac, M.D., PhD \\ County general hospital Vinkovci \\ Zvonarska 57, 32100 Vinkovci \\ E-mail: antun.sumanovac@gmail.com
}




\section{INTRODUCTION}

Ankle arthroscopy has become a widely used tool for the orthopaedic surgeon. According to literature, the complication rate for the procedure varies form $9 \%$ up to $17 \%$ with neurologic injury being the most common. Recent studies show significantly lower complication rates of up to $6.8 \%^{1}$. Other common complications include vascular injury, joint fistula, infection, chronic regional pain syndrome, instrument breakage, deep vein thrombosis and compartment syndrome. latrogenic cartilage damage can occur in up to $31 \%$ of the cases with severe damage in $6.7 \%$. There were no symptoms in these patients at follow-up ${ }^{1}$.

Complete rupture of the common tendon of the extensor digitorum for all four toes (2-5) after ankle arthroscopy is a rare complication. It is of utmost importance not to forget such complication is possible and to diagnose it and treat it as soon as possible.

Urgent, early surgery can enable primary reconstruction of the tendon thus eliminating the need for grafts and significantly reducing morbidity and speeding up the recovery process.

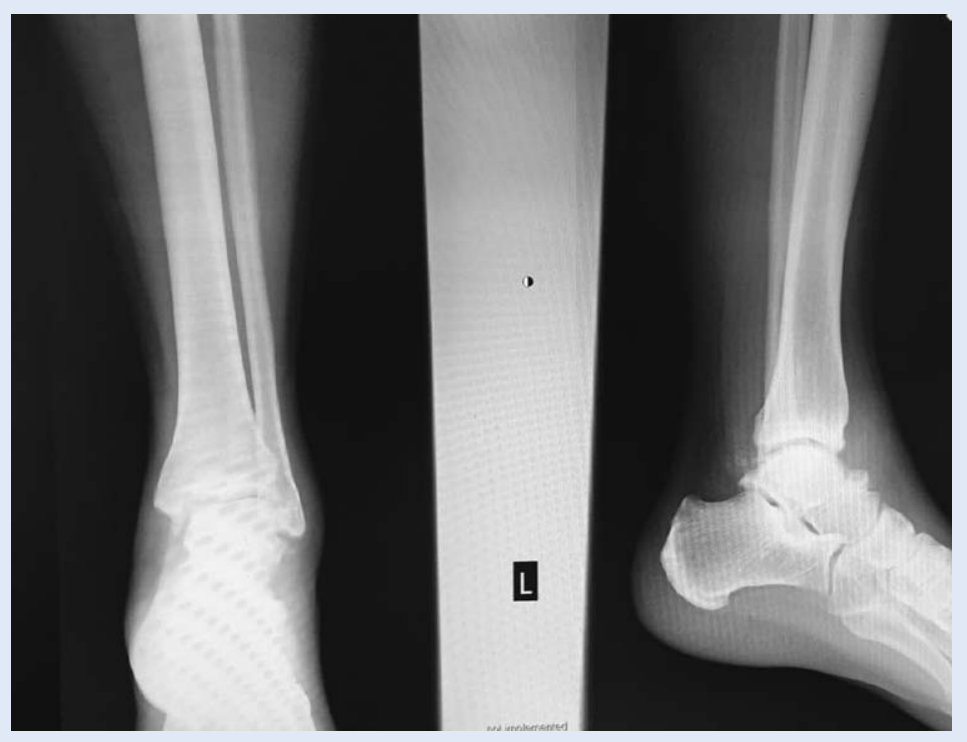

Fig. 1 Preoperative X-ray
Most of the risk of injury occurs during portal placement. Standard method of ankle arthroscopy was published by Takagi in $1939^{2}$. Watanabe published his series of 28 ankle arthroscopies including a detailed discussion of arthroscopic approaches to the ankle in $1972^{3}$. Since then, numerous reports on approaches and ankle arthroscopy techniques have been published.

In this report we present a case of 32-year old police officer who underwent anterior ankle arthroscopy after failed conservative treatment. The patient presented with delayed common extensor digitorum tendon rupture five weeks after the procedure.

\section{CASE REPORT}

A 32-year old police officer who recreationally plays soccer came to our office with symptoms of anterior ankle impingement. Conservative therapy was recommended and conducted in different institution with no improvement on multiple occasions during several months. After being offered to continue with conservative treatment and with continued inability to keep his desired level of activity, he seeked second opinion in our institution. After reviewing preoperative $\mathrm{x}$-rays and MRI and after careful clinical examination, severe anterior ankle impingement was evident (fig. 1). The patient underwent ankle arthroscopy. Thigh tourniquet was applied. Standard anterolateral and anteromedial portals were created $^{1,4}$. No invasive distraction was used. After entering the joint space severe synovial reaction was encountered. Ten loose, cartilaginous bodies were extracted in total. PHD studies confirmed synovial chondromatosis. Furhermore, significant tibial and talar spurs were encountered with ossification of the syndesmosis. The synovium was reduced with the use of radiofrequency probe. The spurs were reduced with the use of arthroscopic high speed burr.

Early postoperative recovery went as expected with no significant swelling of the ankle or drainage from the wounds. The patient was placed in a walking boot and allowed to bear weight as tolerated. After the wounds have healed, standard physical therapy regime was initiated. The patient had no significant pain and had near full ran- 
ge of motion throughout the physical therapy. Five weeks after the procedure, the patient felt a "snap" while dorsiflexing his fingers. He reported swelling in the anterior part of the ankle and could not dorsiflex fingers 2-5 any longer. After reporting to our office, a clinical diagnosis of rupture of the common tendon of the extensor digitorum muscle was eastablished. The diagnosis was later confirmed with an MRI (fig. 2 and 3). The patient underwent urgent open reconstruction of the tendon. During the second procedure, a capsular lesion along with full rupture and scarring of the tendon was found. From the observed damage, it was clear that the cause of rupture was damage made by the radiofrequency probe while performing synovectomy. The capsule was repaired and the tendon stumps debrided. Fortunately, we were able to perform a primary repair so no graft was used. The wound was closed in layers including the extensor retinaculum. The patient was placed in a lower leg cast for 6 weeks after which progressive weight bearing and physical therapy was initiated. The patient made a full recovery and has returned to his desired lifestyle and level of activity.

\section{DISCUSSION}

During our literature review it was clear that injury of the tendons as a result of ankle arthroscopy is uncommon. As reported by Zengerink, the most common complication after ankle arthroscopy is neurologic injury followed by infection ${ }^{5}$. They did not report any tendon ruptures after ankle arthroscopy. In 2010. Tuncer reported a rupture of extensor hallucis longus and extensor digitorum longus for second and third toe ${ }^{6}$ and in 2007 Navadgi reported a rupture of the extensor hallucis longus ${ }^{7}$ To our knowledge, complete rupture of the common tendon of the extensor hallucis longus for all four toes (2-5) is unreported. Since this is a rare complication, it is very important to raise awareness that such complication is a distinct possibility. Preferred modality for definitive diagnosis is MRI imaging which was immediately conducted in our case. One could argue that tendinosis could be the cause of delayed tendon rupture. Kaufmann reported a rupture of two tendons after ankle arthroscopy ${ }^{8}$.

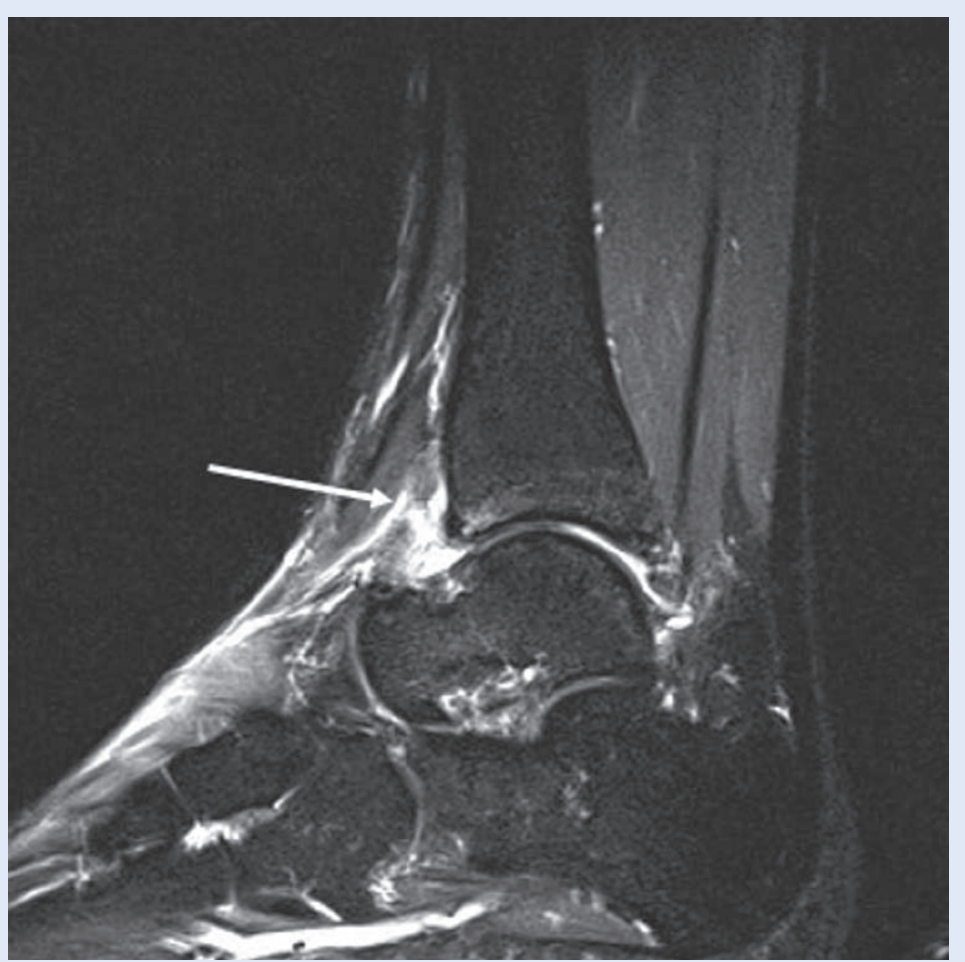

Fig. 2 Capsule rupture

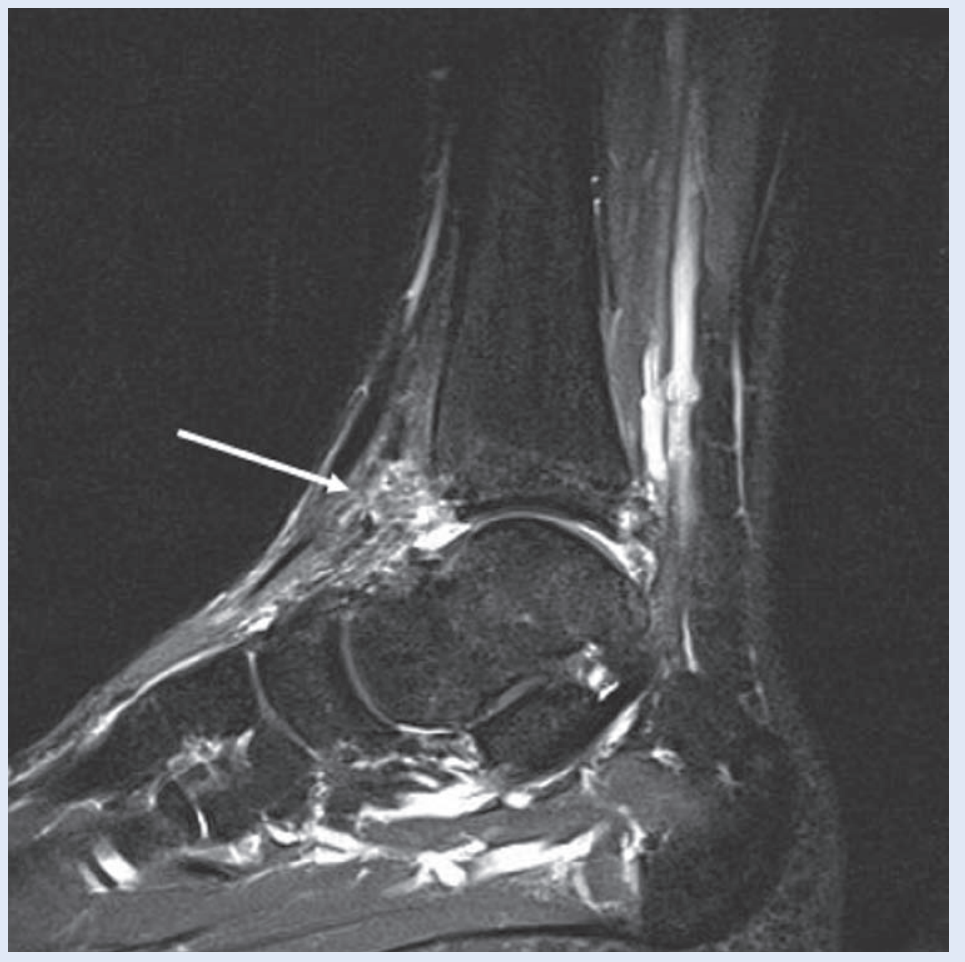

Fig. 3 Tendon rupture

He argued that since MRI after the surgery did not show any micrometallic debris in the soft tissues around the tendons, the rupture was spontaneous and not iatrogenic. The MRI apparatus 
available to us is not sufficiently strong to detect such debris. Furthermore, the level of damage found during the reconstruction procedure excludes any possibility of spontaneous tendon rupture. The fact that we were able to reconstruct the tendon without any need for grafting is probably the result of urgent surgery.

\section{CONCLUSION}

Complete rupture of the common tendon of the extensor digitorum for all four toes (2-5) is a rare complication after ankle arthroscopy. It is therefore very important to keep such possibilty in mind. Our case shows that if such complication does occur, it is of utmost importance not to waste any time and to perform urgent MRI and tendon reconstruction. Swift action can facilitate primary repair without the need for grafting which significantly reduces morbidity and speeds up recovery.

Conflict of interest: Authors declare no conflicts of interest.

\section{REFERENCES}

1. Ishikawa SN. Arthroscopy of the foot and ankle. In: Azar FM, Beaty JH, Canale TS (eds). Campbell's Operative Orthopaedics. 13th ed. Philadelphia: Elsevier, 2017;24712487.

2. Takagi K. The arthroscope. Monograph. Tokyo. Japanese Orthop Assoc 1939;14:359-361.

3. Watanabe M. Selfoc-Arthroscope (Watanabe no. 24 arthroscope). Monograph. Tokyo, Teishin Hospital 1972.

4. Ferkel RD, Fischer SP. Progress in ankle arthroscopy. Clin Orthop Relat Res 1989:210-220.

5. Zengerink $\mathrm{M}$, van Dijk $\mathrm{CN}$. Complications in ankle arthroscopy. Knee Surgery, Sport Traumatol Arthrosc 2012;20:1420-1431.

6. Tuncer S, Aksu N, Isiklar U. Delayed rupture of the extensor hallucis longus and extensor digitorum communis tendons after breaching the anterior capsule with a radiofrequency probe during ankle arthroscopy: A case report. J Foot Ankle Surg 2010;49:490-493.

7. Navadgi BC, Shah N, Jeer PJS, Rajan SS. Rupture of the extensor hallucis longus tendon after ankle arthroscopyAn unusual complication. Foot Ankle Surg 2007;13:4547.

8. Kaufmann J, Newton A, Ghosh P, Ritter Z. Spontaneous double tendon rupture of the ankle. Foot Ankle Online J 2017;10:2-5. 